\title{
A Study On The Educational Problems Of Scheduled Caste People With Special Reference To Biswanath Gaon Panchayat
}

\author{
${ }^{1}$ Minakshi Das \\ ${ }^{1}$ Guest Lecturer, Education Department, Biswanath College, Biswanath(Assam). ${ }^{1}$ minakshidas730@gmail.com
}

\begin{abstract}
Scheduled Castes are the most disadvantaged socio-economic groups in our India. The Scheduled Caste people are scattered all over the country. They are mainly settled in rural areas and are dependent on the upper castes people for their livelihood. The scheduled caste people are mostly engaged in low paid manual occupations and also work as bonded labours. Majority of the scheduled caste people do not conscious in getting education and also unaware about the value of education for their lives. They do not give priority to send their child in school or colleges. Poverty, illiteracy, poor social environment, lack of general awareness etc. are the problem that scheduled caste people suffer from. The Government of India has special schemes to enable access to opportunities including scholarship for education, various educational facilities, financial support and skill building for setting up their lives, reservation in jobs, reservation for getting education and special courts to address instances of atrocities and violence. Though they have various educational schemes and policies but they unaware their rights and opportunities to upgrade their lives. It is utmost important for us to understand and analyses the problems in the context of their previous conditions which continue to have a bearing on the present. This paper identifies and analyses the educational problems of scheduled caste people in Biswanath Gaon Panchayat.
\end{abstract}

Keywords:

Education, Scheduled Caste, Problems, People, Society etc.

Article Received: 18 October 2020, Revised: 3 November 2020, Accepted: 24 December 2020

\section{OBJECTIVES OF THE STUDY}

- To study about the educational problems of Scheduled Caste people in the studied area.

- To identify the various causes of educational backwardness of Scheduled Caste people.

- To find out the measures to solve the problems of education of scheduled caste people.

\section{METHODOLOGY}

Here the investigator applied both primary and secondary sources for preparing this paper. The investigator use simple survey method with the help of questionnaire and observation for collection of data and also use books, magazine, journal, news paper, various published and unpublished records, internet etc. The present study is related with Biswanth Gaon Panchayat of Biswanath Development Block under Biswanath
District, Assam. There are seven villages in this gaon panchayat but because of time constrains it is impossible to cover all the villages. Here only use two villages Natun Gaon and Puroni Gaon were taken for the study. Data were collected from only 100 respondents of the total population by using simple random sampling.

\section{Concept of scheduled caste people-}

Scheduled Casts are the exuntouchables, who continue to follow the Hindu faith. The term scheduled casts was first incorporated into the Govt. of India act of 1935. The purpose of classification of casts as Scheduled Cast is to safeguard the interest of those who suffer from Cast discrimination and to provide for them special concession to help them catch up with the rest of the population in the process of development.

The Govt. of India act 1935, determined these forms of deprivation, particularly social and economic on the bases that- 
- They occupy a law position in Hindu Social Structure.

- They are backward in education.

- They have inadequate representation in Government Services, in the field of trade, commerce and industry.

- They suffer from Social and physical isolation from the rest of the population.

The Scheduled Caste people are backwards, it is due to their poor rural nature, illiteracy, dependence on agricultural labour or other occupations with low earnings, and due to injustice, exploitation and operation. The Schedule Caste have been suffering from three social disabilities-

- Untouchability

- Atrocity( which is an act of extreme cruelty committed against them)

- Bonded labour

The criteria for consideration and inclusive of a particular cast into the schedule were based on its social, educational and economic backwardness arising out of the traditional castoms related to the practice of untouchability.

\section{The Scheduled Castes in India-}

In Indian social hierarchy the Schedule Castes have been considered one of the weakest constituents. They have been attributed so many nomenelatures such as untouchables, harijans, dalits, panchamanes, atisudras, avarnas and antyajas. The term depressed classes refer to those castes which belong to the lowest rang of the Hindu Caste hierarchy and whose touch or proximity is considered polluting by the Caste Hindus. The word " jatita" devotes proverty and their oppressed condition. The " servile classes" phrase was used to devote the servile nature of their working relations with the higher castes and the degraded nature of work with which they were involved like scavenging, sweeping etc. the SC were named as Harijans by Saint Narsimha Mehta and Mahatma Gandhi. The Harijans are those who are entangled subhuman social existence, abject poverty, economic exploitation and a sub- culture of submission and political powerlessness.

The scheduled castes were the former untouchable castes of Hinduism. Besides the four traditional castes there was another group of persons even during the early days of chaturvarnya, who came to be described as untouchables because they were darker skin and were engaged in unclean occupations. These people were the outcastes and as such were socially atrocized by caste Hindus. As the lowest strata in the society, the untouchables formed the fifth varna panchamans/chandals or the fifth caste. They were assigned a position very much lower than that of the sudras. Their hereditary occupations were street sweeping, scavenging, weaving, tanning etc. They were expected to do all the dirty jobs in the society, which others were restrained from doing. The scheduled caste people were stay away from the different levels of upper caste people.

\section{Constitutional Provisions for Scheduled Caste people-}

Article 46 of the Constitution states, "The state shall promote with special care, the education and economic interests of the weaker sections of the people and in particular of the Scheduled Caste and Schedule Tribe and shall protect them from social injustice and all forms of social exploitation." Articles 330, 332, 335, 338 to 342 and the entire fifth and sixth schedules of the constitution deal with special provisions for implementations of the objectives set forth in Article 46. These provisions need to be fully utilized for the benefit of weaker sections in our society.

\section{Data Analysis and Interpretation-}

This part of the present study deals with the findings of the field survey of the sample villages of Biswanath Gaon Panchayat. To know 
the educational problems of Scheduled caste students of the study area selected 100 respondents of the total population by using simple random sampling. The following information were gathered from the study -

Table 1- Educational Achievements of Scheduled Caste Students

\begin{tabular}{|l|l|l|l|l|l|l|}
\hline $\begin{array}{c}\text { Sl. } \\
\text { No }\end{array}$ & Levels of Education & $\begin{array}{c}\text { Total } \\
\text { Respondents }\end{array}$ & Yes & No & $\begin{array}{c}\text { Percentage of } \\
\text { Positive } \\
\text { Response }\end{array}$ & $\begin{array}{c}\text { Percentage of } \\
\text { Negative } \\
\text { Response }\end{array}$ \\
\hline 1 & Primary Education & 100 & 63 & 37 & 63 & 37 \\
\hline 2 & Secondary Education & 100 & 45 & 55 & 45 & 55 \\
\hline 3 & Higher Education & 100 & 12 & 88 & 12 & 88 \\
\hline
\end{tabular}

Table 2- Educational Problems of Scheduled Caste Students

\begin{tabular}{|c|c|c|c|c|c|c|}
\hline $\begin{array}{l}\text { Sl. } \\
\text { No }\end{array}$ & Nature of Problems & $\begin{array}{l}\text { Total } \\
\text { Respondents }\end{array}$ & Yes & No & $\begin{array}{l}\text { Percentage of } \\
\text { Positive } \\
\text { Response }\end{array}$ & $\begin{array}{l}\text { Percentage of } \\
\text { Negative } \\
\text { Response }\end{array}$ \\
\hline 1 & Illiteracy of parents & 100 & 73 & 27 & 73 & 27 \\
\hline 2 & Poverty & 100 & 100 & 00 & 100 & 00 \\
\hline 3 & Lack of interest & 100 & 45 & 65 & 45 & 65 \\
\hline 4 & Lack of guidance & 100 & 80 & 20 & 80 & 20 \\
\hline 5 & $\begin{array}{l}\text { Lack of awareness } \\
\text { towards their rights and } \\
\text { opportunities }\end{array}$ & 100 & 70 & 30 & 70 & 30 \\
\hline 6 & $\begin{array}{l}\text { Unconsciousness of } \\
\text { parents }\end{array}$ & 100 & 31 & 69 & 31 & 69 \\
\hline 7 & $\begin{array}{l}\text { Unhealthy family } \\
\text { environment }\end{array}$ & 100 & 60 & 40 & 60 & 40 \\
\hline 8 & $\begin{array}{l}\text { Lack of Progressive } \\
\text { outlook }\end{array}$ & 100 & 64 & 36 & 64 & 36 \\
\hline
\end{tabular}

\section{FINDINGS}

The present study has brought out a number of problems of using educational problems in the study area which are mentioned as follows-

The educational level of Scheduled Caste people is not satisfactory in the studied area. They have a low educational status. The enrolment and retention of scheduled caste students goes lower and dropout rate goes higher as the level of classes goes higher. The literacy rate of scheduled caste students at primary level is $63 \%$, secondary level is $45 \%$ and higher level is only $12 \%$.

Illiteracy of parents is a big problem that the scheduled caste students face for upgrading their educational life.

Another major problem of scheduled caste students is poverty. Their parents involve in low paid manual income which they cannot give effort to fulfill their children needs.

Lack of interest of students is one of the major issues for their low level of achievement in the field of education. 
Lack of guidance of scheduled caste students is another problem for low achievement in the level of education.

Most of the scheduled caste people do not aware about their rights and opportunities. A large percentage of SC students are deprived of government funds and incentives.

Another big problem of scheduled caste students is unhealthy family environment. Most of the fathers are addicted to alcohol and beverage items that creating the mental insecurity in their family atmosphere.

Guardian unconsciousness is of the important factor for their minimum level of achievement. They have little knowledge relating to modern society.

Lack of progressive outlook and under privileged conditions to motivate the students towards receiving their optimum level of education.

Socio economic condition is not good in the studied area. Majority of the people involves in fishing, agriculture and bonded labour.

\section{Suggestion-}

Education is the single most important means by which individuals and society can improve personal endowments, build capacity levels, overcome barriers and expand opportunities for a sustained improvement in their well being. But the development of education is one of the important problems in the case of scheduled caste people. For solving the problem of education among scheduled caste people I like to express some idea or suggestion as follows-

- Proper awareness campaign should be organized to create awareness about the importance of education in their lives.

- The attitude of parents towards education should be improved through proper guidance and counseling.

- Vocational institute should be implemented in the backward area for creation of new avenues.
- Establish separate residential school for each district and extended up to pg level.

- Merit scholarship, attendance scholarships and more incentives should be given to the scheduled caste students.

- Administration of incentive need to be streamlined so that the students may avail all the facilities at proper time.

- The traditional occupation has to be regenerated with modern techniques.

- Adult education should be encouraged to motivate the parents regarding the value of education.

- Regarding the constitutional provisions, facilities, plans and schemes for the scheduled caste people should be published in wide range through mass media like television, newspaper, bulletin, wall poster etc.

- The concerned authority should take appropriate steps to provide proper facilities for scheduled caste students.

\section{CONCLUSION-}

Education has been considered as the most important instruments to raise one's position in the society as well as a power to fight against poverty and ignorance. Though educational achievement is open to all, it is not smoothly achievable as have been felt by the students. The government of India has take special schemes to enable access to opportunities including scholarships for education, financial support and skill building for setting up enterprises, reservation in jobs, reservation in getting education for scheduled caste people and special courts to address instances of atrocities and violence. In democratic country like India, it is necessary that educational opportunities should be equalized in our country most of the scheduled caste people are educationally, socially and economically backward. Therefore government has enacted progressive legislation, programs and schemes for the development and empowerment of scheduled caste people. 
Based on the study, it can be concluded that majority of the scheduled caste people are having low literacy status which inturn causes for backwardness with illiteracy, poverty, lack of awareness, lack of guidance etc. In spite of affirmative action with various education as well as development programmes and policies, the status of scheduled caste people has not improved to the desired level in the studied area. It is very very important to give special attention towards scheduled caste people for overall up gradation in the different fields of their lives.

\section{REFERENCES-}

[1] Chauhan, B.R. (1975), Scheduled Caste and Education, Anu Publication, Meerut.

[2] Chatterjee, S.K. (2004), "Educational Development of Scheduled Caste" Gyan Publishing House, New Delhi.

[3] Kaul Lokesh (2009), "Methodology of Educational research" Vikas Publishing House Pvt. Ltd.

[4] Singh, P. (1989), "Problem of Education among Scheduled Castes", Mittal Publication, New Delhi.

[5] Pravathamm C. Satyanarayan (1984), "New Horizon and SCs" Ashish Publication, New Delhi.

[6] Naidu R.V.K. (2004), "Empowerment of Scheduled Castes", Kanpur Publications, Delhi.

[7] Malik S. (1979), "Social Integration of Scheduled Castes", Abhinab Publication, New Delhi.

[8] Vakil, A.K. (1985), "Reservation Policy and Scheduled Castes in India", Ashish Publishing House, New Delhi.

[9] Chitris S. (1975), "Education of Scheduled Castes", Journal of Higher Education; 1(2):167-178.

[10] Sharma C.L. (1996), “ Social Mobility among Scheduled Castes", M.D. Publications Pvt. Ltd. New Delhi.

[11] Lynch OM. (1969), "The Politics of Untouchability, Social Mobility and Social
Change in a city of India", Columbia University Press, New York, US/7.

[12] Aziz A, Sivanna N, Vijay KB, Shyamala CK, (2000), "Rural Development and Scheduled Castes" Journal of Rural Development, 19(2): 219-236.

[13] Agarwalla S. (2012), "Emgerging Issue and Education", Aditya Book Distributors, Guwahati.

[14] Goswami S, and Devi M. (2012), "Emgerging Issue and Education", Shanti Prakashan, Guwahati.

[15] Baruah, KC and Sharma M.M, "Problems of Education in India", Vinod Pustak Mandir, Agra. 